\title{
Knowledge sharing in the automotive sector: a comparative study of chinese and brazilian firms
}

\author{
Jorge Muniz Jr. ${ }^{\text {** }}$ (D), Jacky Hong ${ }^{\mathrm{b}}$ (D), Stefano Oliveira ${ }^{\mathrm{a}}$ (D), Daniel Wintersberger ${ }^{\mathrm{C}}$, \\ Silvio Popadiuk ${ }^{\mathrm{d}}$ \\ aUniversidade Estadual Paulista, Guaratinguetá, SP, Brasil \\ bUniversity of Macau, Macau, China \\ 'University of Birmingham, Birmingham, United Kingdom \\ dUniversidade Presbiteriana Mackenzie, São Paulo, SP, Brasil \\ *jorge.muniz@unesp.br
}

\begin{abstract}
Paper aims: This research aims to evaluate factors that influence knowledge sharing in automotive production context in Brazil and China.

Originality: Despite the growing recognition of the factors that enable knowledge sharing in organizations, our understanding about the unique challenges encountered by the blue-collar workers in a production context is rather limited. Also, the paper raises issues and challenges involved for production organizations to engage in cross-national knowledge sharing, which remain relatively under-explored.
\end{abstract}

Research method: Drawing on the Analytic Hierarchy Process (AHP) approach, we conduct a comparative survey among the production managers in five automotive plants in China and Brazil. The AHP approach is based on Objective: Promote knowledge sharing among production workers; Criteria of knowledge conversion as Socialization, Externalization, Internalization; and Alternatives as Structure, Communication, Training, Incentive, Standard Operating Procedure, Problem Solving Methodology. The methodology focused on the 3 Brazilian and 2 Chinese automotive plants in our fieldwork.

Main findings: While many authors argue that socialization (dialogue) is the key form of worker knowledge sharing, our findings indicate that workers and managers perceive internalisation as more important in the automotive context. The significant differences between Chinese and Brazilian workers on the relative importance they attributed to knowledge sharing processes and corresponding enabling factors reinforce our understanding about the challenges of knowledge sharing across cultures and lends support to a more particularistic debate of knowledge management. While automotive workers in Brazil preferred to receive more training and better incentive schemes as essential knowledge sharing support mechanisms, Chinese workers valued more standardization through structure and standard operation procedures. The study reaffirms the role of knowledge sharing in continuous improvement and incremental innovation in shop floor operations.

Implications for theory and practice: In lieu of the gaps in the extant literature, this research aims to further identify and evaluate factors that influence cross-national knowledge sharing in automotive production contexts. The research addressed the gaps to promote supportive ways to provide employees interaction, best practices and lessons learning sharing.

\section{Keywords}

Knowledge sharing. Brazil. China. Automotive.

How to cite: Muniz Jr., J., Hong, J., Oliveira, S., Wintersberger, D., \& Popadiuk, S. (2019). Knowledge sharing in the automotive sector: a comparative study of chinese and brazilian firms. Production, 29, e20180084. https://doi. org/10.1590/0103-6513.20180084

Received: Sept. 21, 2018; Accepted: May 29, 2019. 


\section{Introduction}

Promoting knowledge sharing has become increasingly important nowadays as organizations aspire to be more adaptable, innovative and sustainable (Lin et al., 2010; Wong \& Aspinwall, 2004) and effective knowledge sharing is perceived to have significant influence on team performance (Cummings, 2004; Hansen, 2002), innovation (Arthur \&t Huntley, 2005; Collins \& Smith, 2006), product development and service quality (Lin, 2007; Mesmer-Magnus \& DeChurch, 2009). Conservative estimates indicate that at least 31.5 billion dollars are lost each year by companies as a result of ineffective knowledge sharing (Babcock, 2004).

However, despite the growing recognition of the factors that enable knowledge sharing in organizations (Tohidinia Ct Mosakhani, 2010; Wang \&t Noe, 2010), our understanding about the unique challenges encountered by blue-collar workers (Muniz Junior et al., 2010a) in production contexts is rather limited. Moreover, prior studies tend to adopt a piecemeal approach by investigating how employee interactions (Zhang \& Jiang, 2015), sharing of best practices (Mura et al., 2013), interpersonal relationships (Van den Hooff \& De Ridder, 2004) and trust (Cleveland \& Ellis, 2015; Fteimi, \& Lehner, 2016; Sorensen, 2015) can facilitate knowledge sharing. For filling this conceptual void, Muniz Junior et al. (2010a, b) have developed an integrative approach by aligning factors related to work organisation as well as knowledge management together and examining their overall impact on knowledge sharing in production contexts. But the issues and challenges involved for production organizations to engage in cross-national knowledge sharing remain relatively under-explored.

The literature about worker knowledge sharing indicates relevance to research: Development of human resources within organizations (Hsiao et al., 2011; Ripamonti \&t Scaratti, 2012); Implementation of factors for the success of knowledge sharing management (Wong, 2005; Dalkir et al., 2007; Mahmoud, 2008; Aziz \& Sparrow, 2011); Pragmatic orientations on ways to identify how the manager can develop favourable contexts to encourage processes of knowledge conversion in the organization (Nonaka et al., 2006); Critical reflection on the development of methods for competitive improvement of the business (Hazlett et al., 2005; Nonaka et al., 2006); Knowledge Management Assessment (Park et al., 2010).

As raised in the literature review (section 2), knowledge sharing is conceived as a complex phenomenon with multiple dimensions and the seemingly different cultural norms in two emerging markets, Brazil and China, appear to affect their knowledge sharing behaviours. These aspects give rise to the following two research questions;

RQ1. What are the key factors driving knowledge sharing in production organizations?

RQ2. How does culture influence knowledge sharing in Brazil and China?

In lieu of the above gaps in the extant literature, this research aims to further identify and evaluate factors that influence cross-national knowledge sharing in a production context. Specifically, we adopt an integrative model of knowledge management, production and work organization (Muniz Junior et al., 2010a, b) to conduct a comparative survey study of five automotive plants in China and Brazil by examining how the production managers and supervisors can develop favourable contexts to facilitate knowledge sharing among blue-collar-workers.

The Chinese and Brazilian automotive industry has great significance. Foreign direct investment in both these countries has strongly increased in the last decade indicating their important roles in the global market. With an investment of US\$91.5 billion, a return of almost US\$2 trillion and 5.0\% of total employment worldwide in 2014 (Statisca, 2018), the automotive industry represents a good context for studying knowledge sharing practices. Global customer demand is on the rise both in mature and emerging markets. Specifically, China and Brazil (both in the global top 10 in terms of vehicles produced) produced over 32 million and two million cars respectively in 2017 (Organisation Internationale des Constructeurs d'Automobiles, 2018). Recent changes of industry consolidation and layoffs only added some pressures to the incumbent firms for enhancing their competitiveness through knowledge sharing.

Drawing on the analytic hierarchy process (AHP) approach (Saaty, 1980) to knowledge sharing as a new domain of multidisciplinary research (Weiming, 2003 apud Evangelou \&t Karacapilidis, 2005), we hope to contribute to a better understanding of how knowledge, work and production-related factors can influence the process of knowledge sharing in production organizations, thus filling this conceptual void in knowledge management research.

The paper is structured as follows. We will first review the background literature and define the three sets of key factors (work, knowledge and production) affecting knowledge sharing in production contexts, followed by a discussion of key cultural challenges potentially associated with knowledge sharing in Brazil and China. In the methodology we then introduce the analytic hierarchy process (AHP) approach and its application to knowledge management as our research methodology and report the main findings. Finally, we will conclude the paper by highlighting the implications for theory and areas for future research. 


\section{Literature review}

Knowledge management $(\mathrm{KM})$ as an evolving research domain has gained rapid attention and recognition in recent years (Collins \&t Clark, 2003; Paiva et al., 2007; Serenko \&t Bontis, 2004). Among various processes involved in knowledge management, knowledge sharing remains a critical activity for organizations since the overall effectiveness and efficiency depends on how well the current know-how and best practices can be shared and transferred among members in organizations (Hong et al., 2011). Knowledge sharing concerns how to transfer expertise and knowledge from the knowledge bearers to novices (Kuo \& Young, 2008; Hendriks, 2001; Hinds et al., 2001). It is a process where people share task relevant ideas, information, and suggestions (Eze et al., 2013) among individuals, groups, teams, departments, and organizations (Crossan et al., 1999; lpe, 2003).

As pointed out by Polanyi (2009), people know more than they realize. Generally, tacit knowledge is difficult to share because of its subjective and ambiguous character inherent to each employee as well as the difficulty of identification and articulation of this knowledge (Mclnerney \& Mclnerney, 2006). Therefore, it is argued that experienced workers should work with novices (Fuller et al., 2005) for sharing their own tacit knowledge within an engaging organizational environment characterized by intensive communication, a strong sense of belongingness, and a social climate characterised by trust and openness (Bresnen et al., 2003; Nakano et al., 2013).

\subsection{Knowledge sharing in production contexts}

Vergison (cited in Rajkumar, 2001, p. 4) identify two independent streams of knowledge management research in production contexts. The micro scale, focussing on the use of knowledge at the shop floor level and the macro-scale which focusses on the business unit level. In this article, we focus on the micro-scale. In this context, Grotenhuis \& Weggeman (2002) indicate that the interaction between the source of knowledge and knowledge receiver in the knowledge sharing process can avoid duplication and reduce redundant work, create knowledge with the help of experts and experienced people, provide some direction for the aspiring and enthusiastic workers to become experts and solve problems in the primary phase which can save time, money, and labour. Examples of knowledge sharing practices in production contexts include the on-the-job training of novice operators by an experienced one, practical interactions among operators during the day-by-day activities, and the discussion of problems and solutions during kaizen (continuous improvement) events.

Regarding blue collar workers, knowledge sharing is claimed to contribute to the creation and improvement of processes, products and services, which arises as a result of shared experiences and collective sense making, depending on the diversity (in terms of personality, perspectives and approaches to problem-solving) and synergy between the different perspectives of its members. Systematically, the experiences of the workers should be shared with the organization. There are many sources of knowledge that contribute to the improvement of results, including job rotation, learning by doing, formal training, quality manuals, standard operating procedures, suggestions schemes, innovations, new practices and problem solving methods. Important features to be developed and directly linked to the sharing of knowledge, as stressed by Haynes (1999), include functional flexibility, versatility and multitasking where workers are trained to be qualified to perform a variety of jobs.

\subsection{Key dimensions and related factors for knowledge sharing in production organizations}

Muniz Junior et al. (2010a) indicate that knowledge sharing among blue-collar workers is socially constructed in a model of knowledge management on the shop floor based on the integration of the following three dimensions.

- Knowledge (K): A set of systematic, formal and deliberate actions aimed at capturing, preserving, sharing and reusing tacit and explicit knowledge created and used by people during routine improvement and production processes, thus generating measurable results for the organization and individuals;

- Work organization (W): All issues related to job design as well as other HRM practices;

- Production organization (P): Entailing the management of tangible resources used in the production process of services and goods.

Under each of these three broad dimensions, there are different enabling factors to provide support and incentives among blue-collar workers in a production environment (Erden et al., 2008; Nakano et al., 2013). The factors identified in the literature that indicate the integration of production, knowledge and work dimensions and support knowledge conversion are summarized in Table 1 (see methodology to details of factors selection). 
Table 1. Dimensions of Knowledge Sharing and Related Factors in Production Organizations.

\begin{tabular}{|c|c|c|c|c|c|c|c|c|c|c|}
\hline \multirow{2}{*}{$\begin{array}{c}\text { Code } \\
\text { References }\end{array}$} & \multicolumn{4}{|c|}{ K - Dimension } & \multicolumn{4}{|c|}{ W - Dimension } & \multicolumn{2}{|c|}{ P - Dimension } \\
\hline & SOC & EXT & INT & CBN & STR & com & TRN & $\mathrm{INC}$ & PSM & SOP \\
\hline \multicolumn{11}{|l|}{ Nonaka \& Nishigushi (2001) } \\
\hline \multicolumn{11}{|l|}{ Tynjälä (2008) } \\
\hline \multicolumn{11}{|l|}{ Van den Hooff \& De Ridder (2004) } \\
\hline \multicolumn{11}{|l|}{ Bisalyaputra (2004) } \\
\hline \multicolumn{11}{|l|}{ Mayer \& Gavin (2005) } \\
\hline \multicolumn{11}{|l|}{ Chennamaneni (2007) } \\
\hline \multicolumn{11}{|l|}{ Nonaka et al. (2006) } \\
\hline \multicolumn{11}{|l|}{ Worley \& Doolen (2006) } \\
\hline \multicolumn{11}{|l|}{ Peltokorpi (2007) } \\
\hline \multicolumn{11}{|l|}{ Spender \& Scherer (2007) } \\
\hline \multicolumn{11}{|l|}{ Kulkarni (2007) } \\
\hline \multicolumn{11}{|l|}{ Søndergaard et al. (2007) } \\
\hline \multicolumn{11}{|l|}{ Mahmoud (2008) } \\
\hline \multicolumn{11}{|l|}{ Taylor \& Murthy (2009) } \\
\hline \multicolumn{11}{|l|}{ Allameh \& Abbas (2010) } \\
\hline \multicolumn{11}{|l|}{ Tohidinia \& Mosakhani (2010) } \\
\hline \multicolumn{11}{|l|}{ Muniz Junior et al. (2010a, b) } \\
\hline \multicolumn{11}{|l|}{ Tohidinia \& Mosakhani (2010) } \\
\hline \multicolumn{11}{|l|}{ Wang \& Noe (2010) } \\
\hline \multicolumn{11}{|l|}{ Yuanlin et al. (2011) } \\
\hline \multicolumn{11}{|l|}{ Wong \& Aspinwall (2004) } \\
\hline \multicolumn{11}{|l|}{ Nakano et al. (2013) } \\
\hline \multicolumn{11}{|l|}{ Cleveland \& Ellis (2015) } \\
\hline \multicolumn{11}{|l|}{ Asrar-ul-haq \& Anwar (2016) } \\
\hline \multicolumn{11}{|l|}{ Wang \& Noe (2010) } \\
\hline Magnier-Watanabe et al. (2011) & & & & & & & & & & \\
\hline Gonzalez \& Martins (2014) & & & & & & & & & & \\
\hline
\end{tabular}

Subtitles: Socialization (SOC); Externalization (EXT); Internalization (INT); Combination (CBN); Organizational Structure (STR); Communication (COM); Training (TRN); Incentive (INC); Problem Solving Method (PSM); Standard Operating Procedure (SOP).

\subsubsection{Knowledge dimension}

According to Nonaka (1994), new knowledge always originates in people. Drawing on Polanyi's concept of tacit knowledge that is personal and cannot be objectively articulated, Nonaka (1994) presents a model based on the social and interpersonal interactions that represents the four ways of conversion between tacit and explicit knowledge. These including socialization - SOC (including dialogue among employees), externalization - EXT (writing down procedures in the form of standard operating procedures, internalization - INT (entailing the study of standard operating procedures), and combination (to summarise the available information or records into procedures or standard operating procedure - SOP to facilitate the work. However, the knowledge combination process is considered as the responsibility of supporting administration and not applicable at the shop floor.

\subsubsection{Work dimension}

A key work-related factor with an impact on knowledge sharing is the organizational structure - STR. This entails the formal organization of people, material resources and time required for the activities of the working group in order to produce improvements. It is understood as the specification of roles and responsibilities assigned to different persons in a group context comprising operators, supporters and their direct supervision. It also helps specify the availability of material resources (such as equipment, machinery and devices) and time, 
which can be used, in part, for the members of the group to meet, solve problems and discuss goals. These production techniques should be complemented with "face to face" discussions, as this can provide a richer medium for the transfer of knowledge (Holsapple \&t Joshi, 2000). Numerous existing studies have highlighted the potential detriment of overly bureaucratic and hierarchical organizational structures to knowledge sharing, and the potential benefits derived from more organic organizational design, characterized by flatter hierarchies and open and flexible organizational structures (Nonaka \& Takeuchi, 1995; Probst et al., 2000).

Communication - COM appears in the literature as a second key work-related factor with strong relevance to knowledge sharing. It refers to the process in which ideas and feelings are transmitted from person to person, from person to group or from group to group, making it possible for the social interaction to support knowledge sharing. Internal communication comprises the personal relationships between the group members, collaboration and learning, as well as the conduct of the decision-making process, which involves specific actions undertaken to solve a given problem. External communication connotes the support obtained from other groups in order to share improvements, solve problems and align actions. The transfer of knowledge results from the meeting of different perspectives, beliefs and values, but its success depends on the ease of communication and intimacy of their communicators (Azan \&t Sutter, 2010). Therefore, interpersonal trust has been highlighted as a key determinant of employee preparedness to engage in knowledge sharing (Mooradian et al., 2006).

Training - TRN, encompasses the action provided for conducting production activities by ensuring that the members of the group develop the ability to use tools and techniques to assist them in improving their work and performing different jobs. It also seeks to create flexibility for the members to conduct new tasks without breaking their normal work routines (Wong, 2005). Cabrera \&t Cabrera (2005) found training in team-building to increase employee social capital, hence stimulating knowledge sharing behaviours and team-based training in particular, is presented as a key factor to build the close interpersonal relationships (trust) amongst workers that are necessary for knowledge sharing (Cabrera \& Cabrera, 2005, p. 728). Moreover, cross-training, by bringing together employees from different functional areas of the organization has the potential to encourage more cross-functional collaboration, trust and knowledge sharing between different groups of employee (Cabrera \& Cabrera, 2005). Various training programmes are to be integrated into a wider formalized orientation and socialization programme for new employees, as such socialization programmes further enhance common understanding and closer interpersonal ties (Fernie et al., 2003)

Finally, incentives - INC, including intrinsic and extrinsic rewards given in recognition for an individual's productive actions are often presented as a key work-related factor that facilitates knowledge sharing. For example, Bartol \& Srivastava (2002) have linked organizational reward systems which reward employees for contributing knowledge to databases is particularly amenable to rewarding knowledge sharing behaviours due to the relative ease of quantification of such behaviours. They also argue that collective reward (i.e. reward such as bonus payments contingent on group or team, rather than individual performance) encourages knowledge sharing as they create a sense of shared ownership, feeling of cooperation and commitment between employees. Such collective rewards could include profit sharing as well as employee share ownership programmes (Bartol \&t Srivastava, 2002, p. 64). While the contribution of explicit knowledge to databases is relatively easily measurable, the sharing of tacit knowledge (e.g. through informal interactions) is more difficult to grasp, measure and directly reward. In this context, a reward system that encourages such behaviours would have to be one which creates trust between workers and their employers and this can indirectly be achieved through reward systems.

\subsubsection{Production dimension}

Within the production dimension, problem solving methods (PSM), identify a sequence of steps to perform the necessary analysis problems encountered and to solve the undesirable results. Worley \& Doolen (2006) suggest that the use of problem solving methods can strengthen the communication between workers and develop a shared understanding of organizational goals, hence facilitating knowledge sharing. Standard operating procedures - SOP, in turn codify a formal description of the work for each of the operators during the production process, and by facilitating worker bottom-up communication, promote participatory management and horizontal communication in the workplace (Biazzo \& Panizzolo, 2000).

Knowledge sharing in production systems also faces some significant barriers, such as lack of management commitment and trust among people, lack of resources, interpersonal conflicts, underestimation of the knowledge contributions from lower levels, threats to self-image, lack of understanding of the organization's processes, ambiguous communication or terminology used, dysfunctional group dynamics (e.g. where people retain knowledge as a source of power), difference in experience levels and intolerance due to past mistakes (Kathiravelu et al., 2013; Riege, 2005; Tonet \&t Paz, 2006; Devinatz, 2007). Models that promote the integration of people, knowledge and production dimensions normally observe tacit and explicit knowledge conversion 
modes, and they are important in guiding formal procedures to support shop floor knowledge sharing activities. But the conversion process between tacit and explicit knowledge to achieve organizational results is not well specified in the theory (Gourlay, 2006).

Summarizing, the need of managing all these enabling factors and integrating them into the knowledge $(\mathrm{K})$, production $(\mathrm{P})$ and work $(\mathrm{W})$ dimensions at the same time appears as a major challenge for knowledge sharing in production contexts. For example, operators receive training in problem-solving methods (PSM), which is supported by day-to-day operations deployed in the form of standard operating procedures (SOP) to prevent undesirable outcomes to relapse. This is also a good opportunity for promoting Socialization among the workers involved and the subsequent internalization of this learning process. This example highlights the interplay between factors related to knowledge management, work and production-related factors.

Given the multiplicity of potential enabling factors that affect knowledge sharing among blue-collar workers, it is imperative to understand and establish their inter-relationships (Lin et al., 2009). Although previous studies have identified the key conceptual dimensions and various underlying factors that enable knowledge sharing among blue-collar workers in a production context (Muniz Junior et al., 2010a, b), the importance of these factors and how the related impact varies across countries have not been empirically determined and still remain a nascent research opportunity. The following section will provide a brief review on knowledge sharing in emerging markets with a specific reference to Brazil and China.

\subsection{Cultural barriers to knowledge sharing in China and Brazil}

The changing landscape of international competition, accompanied by the rise of multinationals from emerging markets (Williamson \& Zeng, 2009), have created a paradigm shift among knowledge management scholars in favor of a particularistic approach of researching knowledge sharing (Hong et al., 2017). Being two major players in the BRICS economies (Klafke et al., 2016), Brazil and China provide a fertile setting for examining the impact of context-specific cultural and institutional contextual conditions on knowledge sharing in production environments (Tong \& Mitra, 2009).

Cultural factors impacting on knowledge sharing may stem both from organizational (Gonzalez \& Martins, 2014) as well as national culture (Ardichvili et al., 2006; Gonzalez \&t Martins, 2014; Barachini, 2009). As organizational culture is influenced by national culture, we need to consider relevant cultural frameworks which may help us understand our context. Both China and Brazil score high on Hofstede's dimension of collectivism, and it would therefore be expected that workers in both countries are likely to be reluctant to share knowledge with members of the organisation with which weak or no social ties exist. Moreover, as "high context" communication cultures, workers in Brazil and China are likely to look for contextual cues in information and tend to disregard information in writing. Employees tend to rely more on the context of non-verbal actions and the environmental setting to convey meaning, and therefore tend to prefer communication media with high media-richness, such as face-to-face communication or phone calls (Ardichvili et al., 2006).

While collectivism facilitates trust and knowledge-sharing with "in group" members, there is usually skepticism towards "outsiders". Therefore, China remains a challenging setting for encouraging knowledge sharing amongst the workforce (Chen et al., 2010; Huang et al., 2008; Jolly, 2002; Ma et al., 2014; McAdam et al., 2012; Tong \& Mitra, 2009). First, the strong emphasis on particularistic and intense social relationships (Weir Et Hutchings, 2005) among Chinese workers may hinder the knowledge sharing processes. Specifically, Chinese people are found to be hesitant to share valuable information to other employees who are considered not as part of the "in-group" members, as revealed for example in a comparison between manager views in Australian and Taiwanese-owned firms (Chow et al., 1999). Due to their seemingly low trust towards outsiders and a fear of potential loss of individual gains (Ding et al., 2016), it is seen as inconceivable for the Chinese to devote considerable time for converting privately held tacit knowledge into public domains that can be accessible by everyone in organizations. The same would be expected in Brazil, however, a comparative study on knowledge sharing in plants in Brazil, China and Russia, found that Brazilian employees are the most enthusiastic about sharing information with others in their organization (Ardichvili et al., 2006).

Deference to hierarchy creates another cultural specific barrier for knowledge sharing. No less so in China (Hong et al., 2006), where respect for the leaders together with top-down decision making processes appear to undermine the effectiveness of knowledge sharing as "[...] employees are reluctant to share information with managers as that would cause loss of face to a manager [...]" (Weir \&t Hutchings, 2005, p. 95). In a Confucian society where hierarchical systems of domination exist in the authority chains (Hong \&t Engestrom, 2004), it will be seen as disrespectful and defiant if subordinates dare to openly express opinions that are divergent from those of the superiors. This may limit opportunities for constructive debates and reflexive thinking that are crucial for knowledge sharing. 
Another potential constraint to knowledge sharing is the fear of "losing face". The Ardichvili et al. (2006), found that Chinese Employees are often unlikely to be stimulated to speak a lot in public and to stand out. Most employees feel rather comfortable asking questions and contributions to discussions in public, as long as these interactions contribute to improved job performance. Brazilian employees seem to be willing to ask questions more often, without much concern for being perceived boastful or immodest. Employees perceived knowledge sharing as enhancing their prospects of future job promotions.

Third, the role of face, or mianzi, and the importance of face-saving for Chinese (Buckley et al., 2006; Ding et al., 2016) exert some emotional pressures on the knowledge seekers, thus implicating their social interactions with the knowledge contributors. Especially for those with higher hierarchical position, fear of losing their social standing and authority in front of their peers or subordinates might undermine their willingness to raise request for knowledge sharing (McAdam et al., 2012).

\section{Methodology}

\subsection{Overall design}

The methodology for our study consisted of two main steps. In the first step, we conducted a comprehensive literature review on knowledge sharing based on the published studies from ISI Web of Science, which updated the literature review of Muniz Junior et al. (2010a). The methodology to papers critical review follows Nakano Et Muniz Junior (2018).

After the literature review, we identified a number of key enabling factors of knowledge sharing in production contexts (See Table 1), which are used as different assessment criteria by the production managers.

In the second step, we focused on the Brazilian and Chinese automotive industry in our fieldwork.

\subsection{Data collection}

We conducted our fieldwork at three Brazilian and two Chinese automotive plants (2015-2016). The choice of automotive industry is based on it is considered as a "[...] microcosm where the key problems of today's production technologies and work organization in general are crystallized and can be observed [...]" (Biazzo \&t Panizzolo, 2000, p. 2).

Our automotive plants samples covered the main processes, such as car and engine assemblers, part-makers and suppliers. The wide coverage of sampling allowed us to generate a landscape of knowledge sharing practices among the workers. The plants profiles are detailed in Table 2. The Brazil and China were chosen for the study because both countries belonged to the group of emerging economies (Ramamurti \& Singh, 2009), with similar industrial contexts both holding a significant share of production volume in the global automotive industry.

Table 2. Background of companies.

\begin{tabular}{|c|c|c|c|c|c|}
\hline Company & Country & Origin & Products & Number of Respondents & Production Responsibilities \\
\hline B1 & Brazil & Sweden & Engines & 30 & $\begin{array}{l}\text { Testing, painting, maintenance, } \\
\text { manufacturing, machining, } \\
\text { transmission, engine assembly, } \\
\text { gearbox and powertrain }\end{array}$ \\
\hline B2 & Brazil & France & Light commercial vehicles & 20 & Assembly and maintenance \\
\hline B3 & Brazil & Brazil & $\begin{array}{l}\text { Chassis, girders, structural } \\
\text { components for body and } \\
\text { chassis, lightweight components } \\
\text { and other metal products }\end{array}$ & 29 & $\begin{array}{c}\text { Chassis assembly, painting, } \\
\text { light pressed, medium and } \\
\text { heavy }\end{array}$ \\
\hline $\mathrm{C} 1$ & China & Japan & $\begin{array}{l}\text { Light private vehicles } \\
\text { Light buses } \\
\text { SUVs }\end{array}$ & 20 & Assembly and testing \\
\hline $\mathrm{C} 2$ & China & China & $\begin{array}{c}\text { Light private vehicles } \\
\text { Light buses }\end{array}$ & 57 & $\begin{array}{l}\text { Design, development and } \\
\text { manufacturing }\end{array}$ \\
\hline
\end{tabular}

Brazil has over 26 vehicles assemblers plants (Associacao Nacional dos Fabricantes de Veiculos Automotores, 2019), while China has over 70 production plants. Among them, many are joint-ventures involving foreign automotive manufacturers, such as BMW, Toyota, Honda, Nissan, VW and Mercedez. 
We adopted a convenience sampling (Rea \& Parker, 2005) approach entailing snowball sampling with the help of managers and purposive sampling in order to control the influence of other unrelated factors and define the scope for selecting the production plants. Apart from the main disadvantage that convenience sample can lead to either under-representation or over-representation of particular group, this sampling choice provides significant help in gathering useful data and information that would not have been possible using probability sampling techniques. The biases could then be minimized by using unbiased procedures to collect the answers from the managers (Miller \& Strang, 2010). These procedures included follow-ups with survey respondents to verify whether our interpretations of the results are correct.

The Analytic Hierarchy Process (AHP) guided the questionnaire design (Appendix A), which allowed the respondents to assess multiple key factors in hierarchical decision-making process by using Saaty's scale (Saaty, 1980). The questionnaire was developed, translated and back-translated by both authors who are native speakers in Brazilian (Portuguese) and Chinese (Mandarin) language.

We followed some predetermined criteria to select the interviewee samples in both countries. These included that interviewees should have (1) at least 5 years production experience, (2) a broad range of technical expertise and (3) at least rudimentary managerial responsibilities related to shopfloor (e.g. supervisors, leaders and managers). Our objective was to ensure that they should have a sufficient understanding about the knowledge, production and work related factors for answering the questionnaires.

\subsection{Survey development and analysis of data through AHP}

Potentially significant knowledge sharing factors were selected based on a systematic literature review that started in 2010 (Muniz Junior et al., 2010a, b) and was updated in 2017 through a systematic search on web of science and scopus databases, using the descriptors knowledge sharing. Items for the AHP were developed and validated in researches (Nascimento et al., 2017; Muniz Junior et al., 2014). Another round of personal interviews with some respondents revealed that the factors selected seem to provide sufficient construct and validity, though for future research we would aim to validity test the items using Cronbach's Alpha. Overall, feedback from respondents indicates that we provided sufficient coverage of all factors, and that no additional factors (beyond those in our study) were deemed relevant to knowledge sharing. We also used interviews to seek feedback on issues around design, layout and structure of the survey, as well as the clarity of the response options provided. No refinement to the survey would be necessary based on the respondent feedback.

The relative comparison of several factors is a complex decision problem, which involves a mix of qualitative and quantitative judgment from those familiar with the issue. It is not easy to express some of these factors in measurable units and difficult to structure the evaluation criteria into an analytical framework to facilitate an understanding of the research phenomenon.

The use of Analytic Hierarchy Process (AHP) developed by Saaty (1980) to some extent addresses these concerns. AHP, as a multi-criteria decision method, decomposes complex decision-making problems (i.e. with multiple judgments at different levels) into sub-problems with hierarchical levels (see for example Nascimento et al., 2017). Each hierarchical level represents a set of attributes or alternatives related to each sub-problem. The top level of the entire hierarchy represents the goal of the problem, which in the presented study, is better knowledge sharing among blue collar workers. An important step for the AHP method is the structuring of the decision problem into hierarchical levels and the construction of a model that relates the factors in terms of their priorities. In this step the overall objective, the criteria and the alternatives are identified. Next, the judgments issued by people involved with the decision in question are collected. Following the identification of the objective (better sharing of worker knowledge), at the next level, we discerned three major sub-categories, namely Socialization (communication) Externalization (written down codes of practice and rules) as well as Internalization (the studying and/or reading of such codes of practices and rules). Finally, we considered different alternative tools to reach the means of better knowledge sharing, some of which included alternatives including formal communication channels, the forging of informal personal relationships etc - see Appendix A.

Thus, for this research, the AHP structure is defined by goals (i.e. better knowledge sharing on the shop floor) and its evaluation criteria (socialisation, externalisation, internalisation) as well as factors relevant to the organisation of work and production). The factors applied were selected based on their relevance to promote the use of worker knowledge and engagement (Muniz Junior et al., 2010b). It then uses pairwise comparisons to model mutual interaction between the different elements and then measures and ranks their impact on the entire system. The relative order of importance between the elements, which is the objective of the knowledge sharing factors evaluation, is obtained. Figure 1 represents the AHP structure to support our evaluation of the critical factors: 


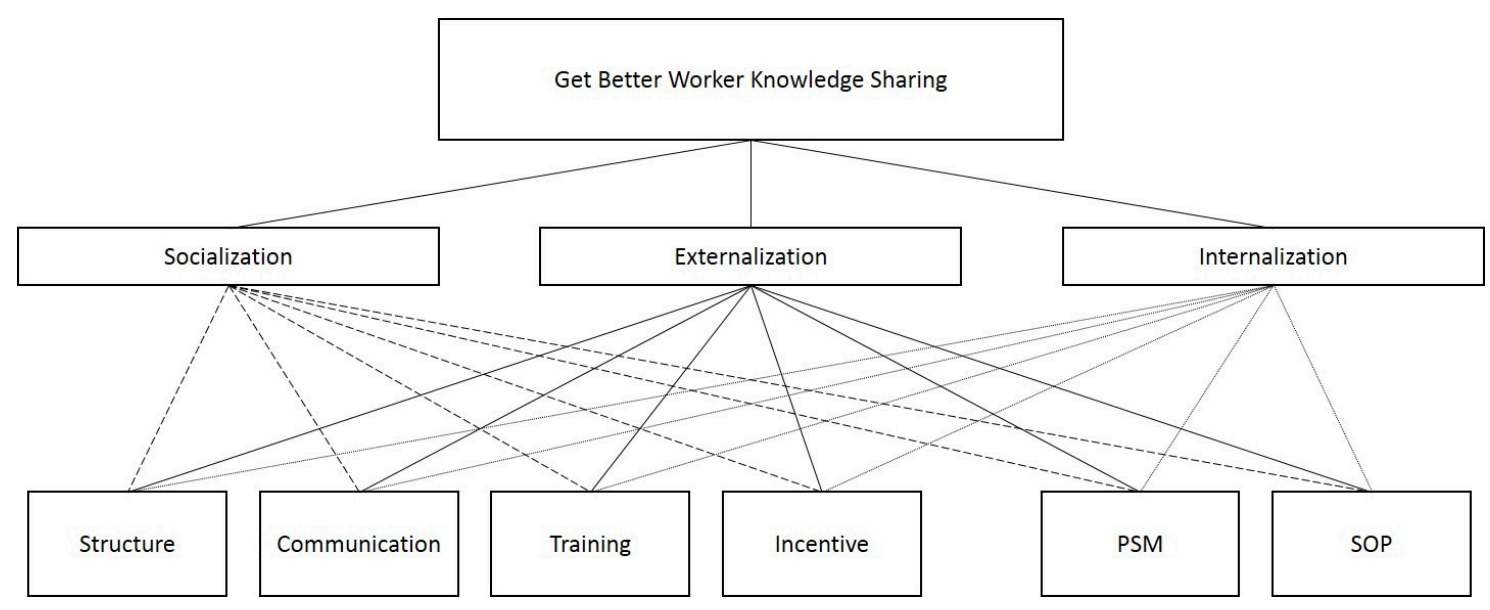

Figure 1. Analytic Hierarchy Process Structure for knowledge sharing.

The Analytic Hierarchy Process (AHP) guided the questionnaire design (Appendix A), which allowed the respondents to assess multiple key factors in hierarchical decision-making process by using Saaty's scale (Saaty, 1980). The questionnaire was developed, translated and back-translated by both authors who are native speakers in Brazilian (Portuguese) and Chinese (Mandarin) language. Figure 2 shows an example of two survey items and the comparison options available to respondents. We used the following five-point likert scale consistent with Saaty (1980).

To ensure improved Knowledge Sharing between Workers, based on the scale, check the relative significance to the following alternatives:

\begin{tabular}{|c|c|c|c|c|c|c|c|c|c|c|}
\hline $\begin{array}{c}\text { Conversation among } \\
\text { plant workers }\end{array}$ & 9 & 7 & 5 & 3 & 1 & 3 & 5 & 7 & 9 & $\begin{array}{c}\text { Update the work } \\
\text { instruction }\end{array}$ \\
\hline $\begin{array}{c}\text { Update the work } \\
\text { instruction }\end{array}$ & 9 & 7 & 5 & 3 & 1 & 3 & 5 & 7 & 9 & $\begin{array}{c}\text { Studying the Standard } \\
\text { Operating Procedure }\end{array}$ \\
\hline $\begin{array}{c}\text { Conversation among } \\
\text { colleagues }\end{array}$ & 9 & 7 & 5 & 3 & 1 & 3 & 5 & 7 & 9 & $\begin{array}{c}\text { Study the work } \\
\text { instructions }\end{array}$ \\
\hline
\end{tabular}

Figure 2. Question example for the respondent compare two different factors.

All 156 sampled participants responded to a paper copy of the questionnaire (Appendix A), disseminated and collected by the researchers. All participants completed the survey in the same room (on the factory premises) within an hour, after being introduced to the general purpose of the research by the researchers, and being given assurance that the research is academic in nature and has no relation with the Consortium plants.

Follow-up personal interviews (individually and the aforementioned two group interviews were conducted a month after the analysis of the survey findings. In each interview, we firstly explained the ranking process based on AHP and then presented participants with the AHP results in order to get their perception on the causes and meaning of these results. Interviews were voice recorded, transcribed and the findings analysed through a sequential coding approach. We looked particularly for the meaning and explanation interviewees attributed to each one of the three dimensions (socialization, externalization and internalization) and the relationship between answers and factors. Each transcribed interview was reviewed by the respective interviewee.

Table 3 illustrates the coding performed in sample answers. For the example, Human Resource representative (Plant S) indicates training (W-TRN) and socialization (K-SOC) factors in the fragment of the answer "train the other colleagues". 


\section{Main findings}

\subsection{Overall analysis}

Our overall results indicated that Internalization (39.07\%) was perceived as the most important process among the automotive assembly line workers in Brazil and China, followed by Socialization (35.62\%) and Externalization (25.31\%) (See Figure 3). This could be related to the rather Taylorist job design we observed in the plants researched (including a strong influence of standard operating procedures), entailing, strong elements of bureaucratic control, automation may force the workers to concentrate more on "getting the work done" rather than spending the extra time on rationalizing the manual work and sharing the insights with others (Ingvaldsen, 2015). As a consequence, the workers' socialization process can be undermined or distorted, and "[...] work may be organized informally and remain dependent on workers' tacit knowledge [...]" (Ingvaldsen, 2015, p. 429). Powell et al. (2004) highlighted that socialization can affect communication quality, which include speed and care, common reference to the workers, relevance and context interpretation.

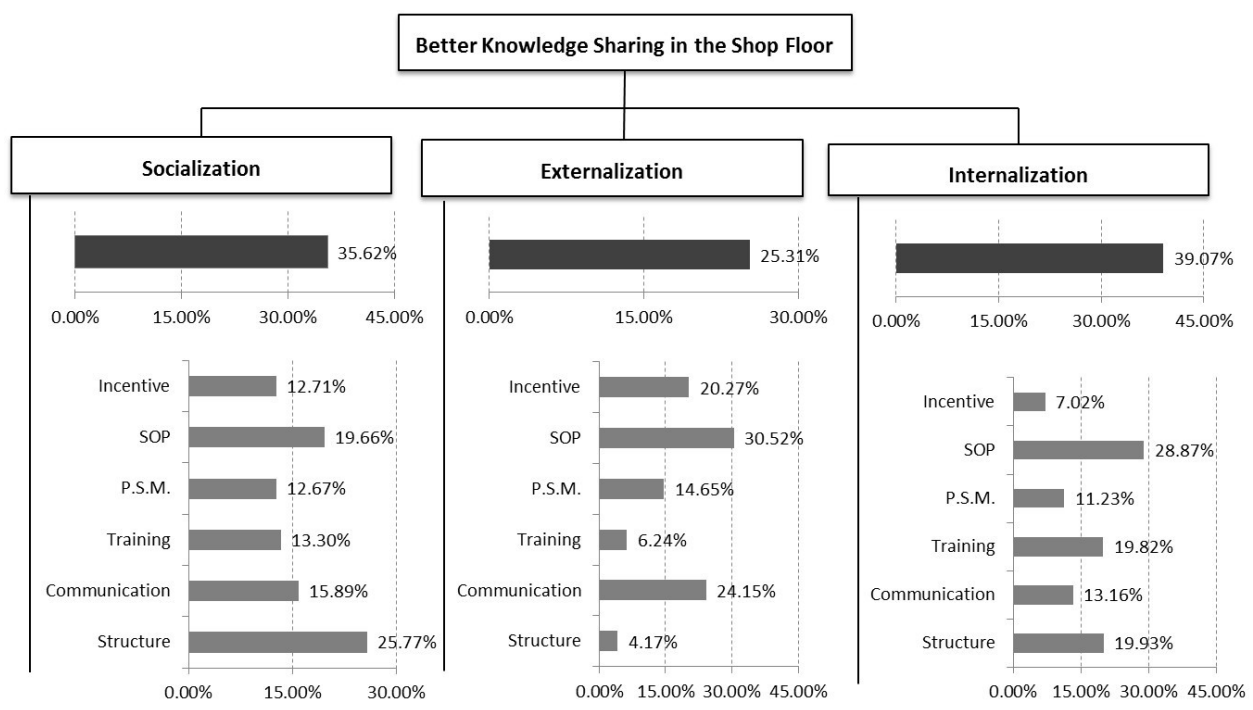

Figure 3. Alternatives and Criteria results from Brazil and China.

As indicated in Table 3 and Figure 4, the major factors reported to be positively influencing knowledge sharing across all manufacturing plants in both countries are standard operating procedures (24.17\%), communication (17.24\%), and training (16.88\%). These factors are related to tacit knowledge socialization through dialogue, observation, imitation and practice supported by tutors and informal meetings. Standard operating procedures (SOPs) represent the main formal technical communication channel between managers and workers. It is observed that managers consider SOPs as a relevant channel for sharing knowledge since they have directly participated in their preparation and approval process. However, workers while enabled to solve problems and propose suggestions for incremental innovation do not necessarily appear to receive a commensurate increase in their autonomy. As concluded by Delbridge et al. (2010), frontline workers contribute with "contextual" knowledge and "conventional" wisdom to the problem solving process. Besides, they also have considerable responsibility for quality control as part of their routine tasks.

Table 3. Examples of content analysis (adapted from Graneheim \& Lundman, 2004).

\begin{tabular}{lll}
\hline \multicolumn{1}{c}{ Meaning unit } & \multicolumn{1}{c}{ Condensed meaning unit } & \multicolumn{1}{c}{ Code } \\
\hline $\begin{array}{l}\text { What happens in the reality is that during the } \\
\text { shift change it is informal and initiative-driven. }\end{array}$ & $\begin{array}{l}\text { during the shift change it is informal and } \\
\text { initiative-driven }\end{array}$ & $\begin{array}{l}\text { Personal Characteristics (W-PCH) } \\
\text { For example, an operator tells what happened } \\
\text { during his work in the previous shift and what }\end{array}$ \\
$\begin{array}{l}\text { his action was. They seek an understanding of } \\
\text { what occurred [...]. }\end{array}$ & & Socialization (K-SOC) \\
& & Communication (W-COM) \\
\hline
\end{tabular}




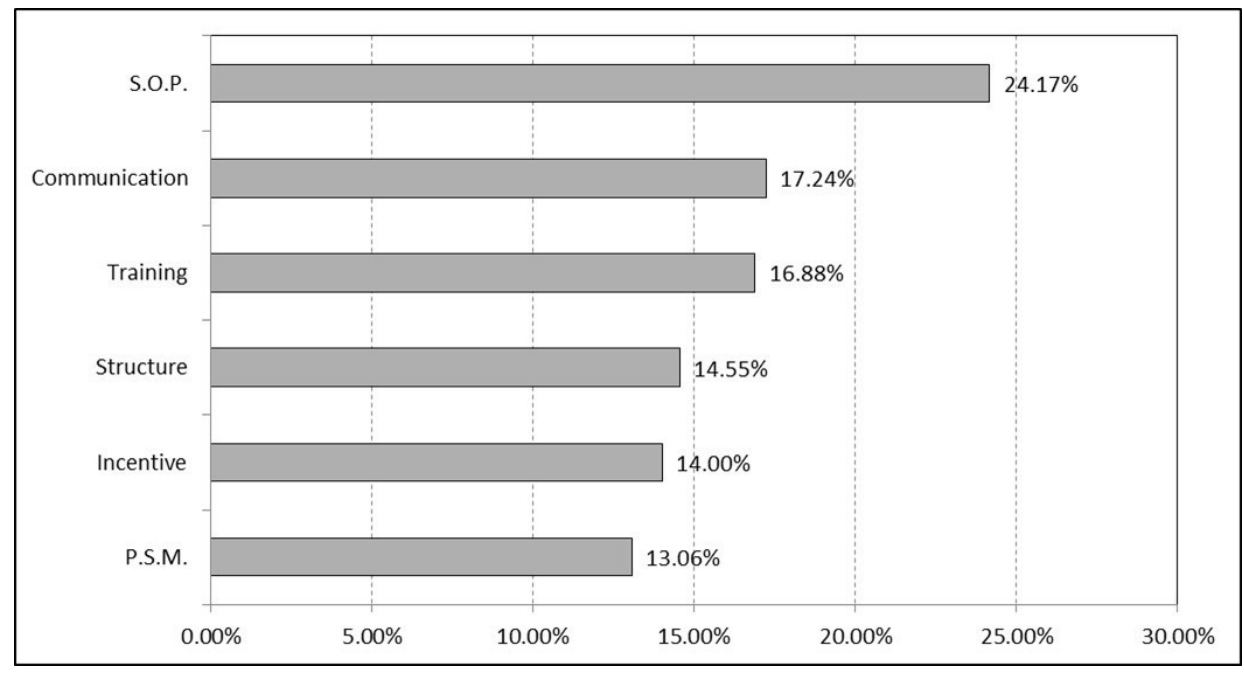

Figure 4. Overall results from Brazil and China.

\subsection{Cross-country comparisons}

Cross-country comparisons are conducted in Table 4. For the Brazilian samples, it's noticed that interpersonal relationships are seen to generate affective bonds (Silva et al., 2015) in a way that provides opportunities for workers to learn together by facilitating the construction of communication channels for sharing knowledge (Chen \& t Huang, 2007). The high importance ascribed to socialization shown in the findings corroborated the worry of managers about the lack of knowledge absorption time due to quick and automatic production cycles. In this case, promoting socialization among workers to avoid incorrect teaching is a fast way to share knowledge and to reduce line workers' withdrawal time of production. Attention is also paid to the speed and care in sending feedbacks and developing a unitarist frame of reference for all members (Powell et al., 2004). With socialization, managers can develop the "common knowledge base" by using figurative language, symbolism as well as individual knowledge to reduce ambiguity and redundancy (Wasonga \& Murphy, 2006), forcing them to focus on practical everyday problems that are important to them rather than the strategic vision of the organization (Sinclair, 2007).

Table 4. Cross-country comparison.

\begin{tabular}{lcc}
\hline \multicolumn{1}{c}{ Criteria } & Brazil (\%) & China (\%) \\
\hline Socialization & 42.40 & 25.47 \\
Externalization & 22.16 & 30.04 \\
Internalization & 35.44 & 44.51 \\
& & \\
Alternatives & & \\
Structure & 8.88 & 23.04 \\
Communication & 16.77 & 17.96 \\
Training & 21.06 & 10.61 \\
Incentive & 16.61 & 10.08 \\
Standard Operating Procedure & 22.30 & 27.24 \\
Problem Solving Methodology & 14.38 & 11.09 \\
& & \\
Respondents & 79 & 77 \\
\hline
\end{tabular}

During the feedback sessions held in Brazilian companies, socialization got a value below expectations for company B1, as the organization invests and maintains several communication ways, as well as scheduled and daily meetings, training workshops and security dialogues. However, on behalf the three companies it is important and necessary to improve the way to establish situations of conversation among workers, promoting formality, information, avoiding teaching erroneously and without rigor, and reducing the withdrawal time 
line of the worker. Attention is also given to the lack of time to absorb knowledge due to fast and automatic production cycles.

For the company B2, the workers is often not valued as knowledge holder and little stuck about his difficulties, which induces the non-recognition of people holding the relevant concepts. Company B3 suggested the creation of discussion session in which supervisors and workers have the same importance and opinion credit.

The low level of socialization shown in the Chinese samples may be linked with the high levels of in-group collectivism (Hofstede, 2001) associated with Chinese culture. We would therefore expect an overall tendency for the learning process to be individualistic, particularly driven by the leaders (Redding, 2008). It is often the managers who are in possession of all critical information to play an influential role during the face-to-face meetings. For the subordinates, due to the prevalent assumption that their opinions and ideas are perceived to be less important and intelligent than those of the leaders, it is likely that they will have less motivation to seek for clarifications and offer suggestions (Chow et al., 1999). Instead of embracing with all subordinates for constructive consultation, the managers would just develop close relationship with a few trusted ones in their inner social circles and listen to their advice. But the final understanding and interpretations will still primarily be based on their own subjective judgment. As time goes by, Chinese subordinates will remain reluctant to engage in independent inquiry or initiatives and defer the decisions to their top most authorities (Farh \& Cheng, 2000).

Throughout the social interchange process, Chinese employees tend to avoid making themselves obvious and exposing their own ideas to public scrutiny (Tang \& Ward, 2003). The concerns for having face-to-face confrontation with the leaders (Chen \& Tjosvold, 2005) reduce their willingness to have socialization with others and challenge the prevalent understandings in meetings. Employees may be culturally hesitant to post their questions or share their answers openly as they fear that their answers might be incorrect (Li et al., 2008; Ribiere \& Zhang, 2010) and make them "lose face" (Leung \&t Yee-kwong Chan, 2003, p. 1575) and hurt their professional reputations.

As a result, this puts excessive social burdens on the Chinese leaders to stimulate lateral flow of knowledge by encouraging participation among co-workers. For example, in a cross-cultural learning setting reported by Hong et al. (2006), the Chinese frontline workers were reluctant to engage in experience sharing and interacting with other members, and they needed to be closely monitored and guided by the Japanese managers for carrying out the team learning activities.

Workers in Brazil, report a low priority for externalization. This result can indicate that a procedure has already been well established on the shop floor. However, from the company's viewpoint, it is necessary to engage in collaborative writing with the understanding that it is part of labour policy and a form of knowledge retention (Colen Et Petelin, 2004) to overcome the semantic boundary (Coradi et al., 2015). The worker can contribute to externalize the knowledge into his own language during the process of knowledge conversion, thus increasing the efficiency and effectiveness of the overall training process.

People in cultures with a low degree of uncertainty avoidance, such as Chinese (Hofstede, 2001), tend to carry out opportunistic information search with limited input from others. Since the decision making process is normally centralized at top management level (Redding, 1990), it is very unlikely that the Chinese managers would engage in frequent social interactions and just rely on their "holistic thinking" to make sense of the situations and produce the interpretative outcomes that are highly uncodified in nature and undiffused within the organizations (Boisot \& Child, 1988). Instead of using rational thinking and formal analysis, they just make use of their personal experience and informal rules to come up with the decisions (Nisbett et al., 2001).

The opportunistic search of information, coupled with the entrepreneurial spirit of Chinese managers, creates a strong bias for action and improvisation. Their weak understanding about the virtues of structured analysis and formal planning (Lang, 1998) forces them to be pragmatic and flexible when dealing with changes and handling the possible contingencies that might occur at the work-site. It is mainly through the constant adjustments and inflections that they draw on and give meaning to the knowledge generated locally to accomplish their collective work.

In Brazil, SOPs and training are the best alternatives to promote knowledge sharing among the frontline workers. The procedures and processes that are supposed to be followed are described in SOPs, and the workers are instructed to value the SOPs that are regularly audited. The purpose is to ensure a better utilization of people and quality assurance. In addition, codifying knowledge into SOP can facilitate the accumulation of experience through learning by doing (Tsai \&t Lee, 2006). According Elmaraghy (2005), the number of decisions to be taken, such as equipment, intensity of tightening mounting direction and ask to be mounted, shall be borne by the operator's skill, even with the instructions and training required, need to rely on individual memory and cognitive ability. 
For Chinese samples, SOPs and training were considered the best alternatives. Liu \& Rao (2015) argue that senior managers have absolute authority for restricting subordinates' access to any important information (Ardichvili et al., 2006; Hofstede, 2001). The lower-level employees also follow the instructions of their supervisors submissively. Senior managers are not willing to share knowledge or collaborate with lower-level employees in any form of communication (Siau et al., 2010). Such one-way, top-down information flow restricts knowledge creation, transfer, and business innovation (Martinsons \& Westwood, 1997). Since Chinese managers perceive information as a strategic tool for manoeuvring, the information sharing process is rather unilateral and restrictive, flowing primarily from top to the bottom (Ahlstrom et al., 2004). The main purpose is to secure hierarchical control and absolute obedience of employees through standardization and formalization (Ding, 2000).

Therefore, the Chinese managers need to accommodate the ambiguities and abstraction as a consequence of the widespread use of uncodified information by structural arrangements (Boisot \&t Child, 1999). Apart from using face-to-face contacts to diffuse information, they also try to make use of the standard operating procedures to help the subordinates for minimizing the need for improvisation.

\section{Conclusion and discussions}

Findings from our study reaffirm the role of knowledge sharing in continuous improvement and incremental innovation in shop floor operations.

Through this study, we aim to make methodological and theoretical contributions to the domain of knowledge management. Firstly, we applied a multi-criteria decision-making analysis tool (AHP) to the issue. To the best of our knowledge, our study was among the first that applied this hierarchical analytical method to assess the knowledge sharing process among production workers. By portraying knowledge sharing as a typical multi-criteria hierarchical decision making problem, we are able to disentangle the relative importance and contributions among different enabling factors for knowledge conversion within the organizations.

Second, while many authors argue that socialization (dialogue) is the key form of worker knowledge sharing (see for example Styhre et al., 2006), our findings indicate that workers and managers perceive internalisation as more important in a production context. The Taylorist work organisation we observed in the assembly process and quick technological changes strongly create an urge for the workers to master and internalize new skills and knowledge as soon as possible. This has reduced their interests to engage in on-going dialogues and socialize with other fellow workers.

Third, the significant differences between Chinese and Brazilian workers on the relative importance they attributed to knowledge sharing processes and corresponding enabling factors reinforce our understanding about the challenges of knowledge sharing across cultures (Hong et al., 2006) and lends support to a more particularistic debate of knowledge management (Glisby \& Holden, 2003). While automotive workers in Brazil preferred to receive more training and better incentive schemes as essential knowledge sharing support mechanisms, Chinese workers valued more standardization through structure and standard operation procedures. This may serve as a strong reminder for 'bringing the culture back' when researching knowledge sharing in organizations (lpe, 2003).

When presenting the survey data, we seek to establish a managerial perspective on their expectation of employees' knowledge sharing behaviour. However, the managerial responses may not necessarily represent by blue-collar workers' perspective, and this is a limitation of this study. Further work is needed to have a better understanding and integration between the managerial and workers perspectives. In addition, there are opportunities to extend the research scope to cover other industries apart from automotive production plants.

The comprehensive factors assessed are representative for Brazilian and Chinese automotive plants and may support managerial initiatives to improve worker knowledge sharing. Cultural aspects influence the factors ranking in both countries. These findings support practical implication as keeps attention to blue-collar workers during the Industry 4.0 implementation.

Further researches about how culture influences knowledge sharing (Ardichvili et al., 2006) is a promisor track to follow, and research questions appears as: What are culture-specific characteristics to influence knowledge sharing? What are the workers perceptions about the factors studied?

\section{Acknowledgements}

The authors gratefully acknowledge the reviewer's comments, which allow the authors to improve the paper. The authors also acknowledge the financial support of the Brazilian research funding agencies CNPq (National Council for Scientific and Technological Development 309028/2015-9) and FAPESP (São Paulo Research Foundation, 2016/00132-2). 


\section{References}

Ahlstrom, D., Chan, E., \& Bruton, G. (2004). Facing constraints to growth? Overseas chinese entrepreneurs and traditional business practice in Asia. Asia Pacific Journal of Management, 21(3), 263-285. http://dx.doi.org/10.1023/B:APJM.0000036463.20310.de.

Allameh, S. M., \& Abbas, S. K. (2010). The relationship between knowledge management practices and innovation level in organizations: case study of sub- companies of selected corporations in the city of Esfahan. Journal of Business Case Studies, 6(1), 89-98.

Ardichvili, A., Maurer, M., Li, W., Wentling, T., \& Stuedemann, R. (2006). Cultural influences on knowledge sharing through online communities of practice. Journal of Knowledge Management, 10(1), 94-107. http://dx.doi.org/10.1108/13673270610650139.

Arthur, J. B., \& Huntley, C. L. (2005). Ramping up the organizational learning curve: assessing the impact of deliberate learning on organizational performance under gain sharing. Academy of Management Journal, 48(6), 1159-1170. http://dx.doi.org/10.5465/ amj.2005.19573115.

Asrar-ul-haq, M., \& Anwar, S. (2016). A systematic review of knowledge management and knowledge sharing: trends, issues, and challenges. Cogent Business \& Management, 14(1), 1-17. https://doi.org/10.1080/23311975.2015.1127744.

Associacao Nacional dos Fabricantes de Veiculos Automotores. (2019). Associados. Retrieved in 2019, April 1, from http://www.anfavea. com.br/associadas.html

Azan, W., \& Sutter, 1. (2010). Knowledge transfer in post-merger integration management: a case study of a multinational healthcare company in greece. Knowledge Management Research and Practice, 8(4), 307-332. http://dx.doi.org/10.1057/kmrp.2010.17.

Aziz, N., \& Sparrow, J. (2011). Patterns of gaining and sharing of knowledge about customers: a study of an Express Parcel Delivery Company. Knowledge Management Research and Practice, 9(1), 29-47. http://dx.doi.org/10.1057/kmrp.2011.3.

Babcock, P. (2004). Shedding light on knowledge management. HR Magazine, 49(5), 46-50.

Barachini, F. (2009). Cultural and social issues for knowledge sharing. Journal of Knowledge Management, 13(1), 98-110. http://dx.doi. org/10.1108/13673270910931198.

Bartol, K. M., \& Srivastava, A. (2002). Encouraging knowledge sharing: the role of organizational reward systems. Journal of Leadership \& Organizational Studies, 9(1), 64-76. http://dx.doi.org/10.1177/107179190200900105.

Biazzo, S., \& Panizzolo, R. (2000). The assessment of work organization in lean production: the relevance of the worker's perspective. Integrated Manufacturing Systems, 11(1), 6-15. http://dx.doi.org/10.1108/09576060010303622.

Bisalyaputra, K. (2004, October). Knowledge transfer as sustainable competitive advantage. In 2004 IEEE International Engineering Management Conference: Vol. 2 (IEEE Cat. No. 04CH37574) (pp. 536-540). USA: IEEE.

Boisot, M., \& Child, J. (1988). The iron law of fiefs: bureaucratic failure and the problem of governance in the Chinese economic reforms. Administrative Science Quarterly, 33(4), 507-527. http://dx.doi.org/10.2307/2392641.

Boisot, M., \& Child, J. (1999). Organization as adaptive systems in complex environments: the case of China. Organization Science, 10(3), 237-252. http://dx.doi.org/10.1287/orsc.10.3.237.

Bresnen, M., Edelman, L., Newell, S., Scarbrough, H., \& Swan, J. (2003). Social practices and the management of knowledge in project environments. International Journal of Project Management, 21(3), 157-166. http://dx.doi.org/10.1016/S0263-7863(02)00090-X.

Buckley, P., Clegg, J., \& Tan, H. (2006). Cultural awareness in knowledge transfer to China: the role of guanxi and mianzi. Journal of World Business, 41(3), 275-288. http://dx.doi.org/10.1016/j.jwb.2006.01.008.

Cabrera, E. F., \& Cabrera, A. (2005). Fostering knowledge sharing through people management practices. International Journal of Human Resource Management, 16(5), 720-735. http://dx.doi.org/10.1080/09585190500083020.

Chen, C. J., \& Huang, J. W. (2007). How organizational climate and structure affect knowledge management-the social interaction perspective. International Journal of Information Management, 27(2), 104-118. http://dx.doi.org/10.1016/j.ijinfomgt.2006.11.001.

Chen, J., Sun, P., \& McQueen, R. (2010). The impact of national cultures on structured knowledge transfer. Journal of Knowledge Management, 14(2), 228-242. http://dx.doi.org/10.1108/13673271011032373.

Chen, Y., \& Tjosvold, D. (2005). Cross-cultural leadership: goal interdependence and leader-member relations in foreign ventures in China. Journal of International Management, 11(3), 417-439. http://dx.doi.org/10.1016/j.intman.2005.06.007.

Chennamaneni, A. (2007). Determinants of knowledge sharing behaviors: developing and testing an integrated theoretical model (Doctor thesis). University of Texas, Arlington.

Chow, C. W., Harrison, G., McKinnon, J. L., \& Wu, A. (1999). Cultural influences on informal information sharing in Chinese and AngloAmerican organizations: an exploratory study. Accounting, Organizations and Society, 24(7), 561-582. http://dx.doi.org/10.1016/ S0361-3682(99)00022-7.

Cleveland, S., \& Ellis, T. J. (2015). Rethinking knowledge sharing barriers: a content analysis of 103 studies. International Journal of Knowledge Management, 11(1), 28-51. http://dx.doi.org/10.4018/1JKM.2015010102.

Colen, K., \& Petelin, R. (2004). Challenges in collaborative writing in the contemporary corporation. Corporate Communications, 9(2), 136-145. http://dx.doi.org/10.1108/13563280410534339.

Collins, C. J., \& Clark, K. D. (2003). Strategic human resources practices, top management team social networks, and firms performance: the role of resource practices in creating organizational competitive advantage. Academy of Management Journal, 46(6), 740-751.

Collins, C. J., \& Smith, K. G. (2006). Knowledge exchange and combination: the role of human resource practices in the performance of high-technology firms. Academy of Management Journal, 49(3), 544-560. http://dx.doi.org/10.5465/amj.2006.21794671.

Coradi, A., Heinzen, M., \& Boutellier, R. (2015). Designing workspaces for cross-functional knowledge sharing in R\&D: the "co-location pilot" of Novartis. Journal of Knowledge Management, 19(2), 236-256. http://dx.doi.org/10.1108/JKM-06-2014-0234.

Crossan, M. M., Lane, H. W., \& White, R. E. (1999). An organizational learning framework: from intuition to institution. Academy of Management Review, 24(3), 522-537. http://dx.doi.org/10.5465/amr.1999.2202135.

Cummings, J. N. (2004). Work groups, structural diversity, and knowledge sharing in a global organization. Management Science, 50(3), 352-364. http://dx.doi.org/10.1287/mnsc. 1030.0134 
Dalkir, K., Wiseman, E., Shulha, M., \& Mclntyre, S. (2007). An intellectual capital evaluation approach in a government organization. Management Decision, 45(9), 1497-1509. http://dx.doi.org/10.1108/00251740710828735.

Delbridge, R., Lowe, J., \& Oliver, N. (2010). Shop floor responsibilities under lean teamwork. Human Relations, 53(11), 1459-1479. http://dx.doi.org/10.1177/00187267005311003.

Devinatz, V. (2007). Manufacturing resistance: rationalizing the irrationality of managerial control on the shop Ffoor in a US medical electronics factory. Employee Responsibilities and Rights Journal, 19(1), 1-15. http://dx.doi.org/10.1007/s10672-006-9028-5.

Ding, G., Liu, H., Huang, Q., \& Gu, J. (2016). Moderating effects of guanxi and face on the relationship between psychological motivation and knowledge-sharing in China. Journal of Knowledge Management. http://dx.doi.org/10.1108/JKM-10-2016-0439.

Ding, X. L. (2000). Systemic irregularity and spontaneous property transformation in the Chinese financial system. The China Quarterly, 163, 655-676. http://dx.doi.org/10.1017/S0305741000014600.

Elmaraghy, H. A. (2005). Flexible and reconfigurable manufacturing systems paradigms. International Journal of Manufacturing Systems, 17(4), 261-276. http://dx.doi.org/10.1007/s10696-006-9028-7.

Erden, Z., von Krogh, G., \& Nonaka, 1. (2008). The quality of group tacit knowledge. The Journal of Strategic Information Systems, 17(1), 4-18. http://dx.doi.org/10.1016/j.jsis.2008.02.002.

Evangelou, C., \& Karacapilidis, N. (2005). On the Interaction between human and knowledge management systems: a framework of knowledge sharing catalysts. Knowledge Management Research and Practice, 3(4), 253-261. http://dx.doi.org/10.1057/palgrave. kmrp.8500076.

Eze, U. C., Goh, G. G. G., Goh, C. Y., \& Tan, T. L. (2013). Perspectives of SMEs on knowledge sharing. Journal of Information and Knowledge Management Systems, 43(2), 210-236.

Farh, J., \& Cheng, B. (2000). A cultural analysis of paternalistic leadership in Chinese organization. In J. Li, Tsui, A. \& Weldon, E. (Eds.), Management and organizations in the chinese context. London: MacMillan Press. http://dx.doi.org/10.1057/9780230511590_5.

Fernie, S., Green, S. D., Weller, S. J., \& Newcombe, R. (2003). Knowledge sharing: context, confusion and controversy. International Journal of Project Management, 21(3), 177-187. http://dx.doi.org/10.1016/S0263-7863(02)00092-3.

Fteimi, N., \& Lehner, F. (2016). Main research topics in knowledge management: a content analysis of ECKM publications. Electronic Journal of Knowledge Management, 14(1), 5-17.

Fuller, A., Hodkinson, H., Hodkinson, P., \& Unwin, L. (2005). Learning as peripheral participation in communities of practice: a reassessment of key concepts in workplace learning. British Educational Research Journal, 31(1), 49-68. http://dx.doi.org/10.1080 /0141192052000310029.

Glisby, M., \& Holden, N. (2003). Contextual constraints in knowledge management theory: the cultural embeddedness of Nonaka's knowledge-creating company. Knowledge and Process Management, 10(1), 29-36. http://dx.doi.org/10.1002/kpm.158.

Gonzalez, R. V. D., \& Martins, M. F. (2014). Mapping the organizational factors that support knowledge management in the Brazilian automotive industry. Journal of Knowledge Management, 18(1), 152-176.

Gourlay, S. (2006). Conceptualizing knowledge creation: a critique of Nonaka's theory. Journal of Management Studies, 43(7), 14151436. http://dx.doi.org/10.1111/j.1467-6486.2006.00637.x.

Graneheim, U. H., \& Lundman, B. (2004). Qualitative content analysis in nursing research: concepts, procedures and measures to achieve trustworthiness. Nurse Education Today, 24(2), 105-112. http://dx.doi.org/10.1016/j.nedt.2003.10.001.

Grotenhuis, F., \& Weggeman, M. P. (2002). Knowledge management in international mergers. Knowledge and Process Management, 9(2), 83-89. http://dx.doi.org/10.1002/kpm.135.

Hansen, T. (2002). The geography of the knowledge economy, innovation, interaction and industrial development (Doctor thesis). University of Copenhagen, Copenhagen.

Haynes, A. (1999). Effects of world class manufacturing on shop floor workers. Journal of European Industrial Training, 23(6), 300-309. http://dx.doi.org/10.1108/03090599910284678.

Hazlett, S.-A., McAdam, R., \& Gallagher, S. (2005). Theory building in knowledge management: in search of paradigms. Journal of Management Inquiry, 14(1), 31-42. http://dx.doi.org/10.1177/1056492604273730.

Hendriks, P. (2001). Many rivers to cross: from ICT to knowledge management systems. Journal of Information Technology, 16(2), 57-72. http://dx.doi.org/10.1080/02683960110054799.

Hinds, P. J., Patterson, M., \& Pfeffer, J. (2001). The effect of expertise on knowledge transfer and subsequent novice performance. Applied Psychology, 86(6), 1232-1243. http://dx.doi.org/10.1037/0021-9010.86.6.1232.

Hofstede, G. (2001). Culture's consequences: comparing values, behaviour, institutions, and organizations across nations (2nd ed.). Thousand Oaks: Sage.

Holsapple, C. W., \& Joshi, K. D. (2000). An investigation of factors that influence the management of knowledge in organizations. The Journal of Strategic Information Systems, 9(2/3), 235-261. http://dx.doi.org/10.1016/S0963-8687(00)00046-9.

Hong, D., Suh, E., \& Koo, C. (2011). Developing strategies for overcoming barriers to knowledge sharing based on conversational knowledge management: a case study of a financial company. Expert Systems with Applications, 38(12), 38. http://dx.doi. org/10.1016/j.eswa.2011.04.072.

Hong, J., \& Engestrom, Y. (2004). Changing principles of communication between Chinese managers and workers. Management Communication Quarterly, 17(4), 552-585. http://dx.doi.org/10.1177/0893318903262266.

Hong, J., Snell, R., \& Easterby-Smith, M. (2006). Cross-cultural influences of organizational learning in MNCs: The case of Japanese companies in China. Journal of International Management, 12(4), 408-429. http://dx.doi.org/10.1016/j.intman.2006.09.005.

Hong, J., Snell, R., \& Rowley, C. (2017). Asia pacific as a research context for organizational learning: background and research directions. Asia Pacific Business Review, 23(4), 467-474. http://dx.doi.org/10.1080/13602381.2017.1346904.

Hsiao, Y. C., Chen, C. J., \& Chang, S. C. (2011). Knowledge management capacity and organizational performance: the social interaction view. International Journal of Manpower, 32(5), 645-660. http://dx.doi.org/10.1108/01437721111158242. 
Huang, Q., Davison, R. M., \& Gu, J. (2008). Impact of personal and cultural factors on knowledge sharing in China. Asia Pacific Journal of Management, 25(3), 451-471. http://dx.doi.org/10.1007/s10490-008-9095-2.

Ingvaldsen, J. A. (2015). Organizational learning: bringing the forces of production back. Organization Studies, 36(4), 423-444. http:// dx.doi.org/10.1177/0170840614561567.

Ipe, M. (2003). Knowledge sharing in organizations: a conceptual framework. Human Resource Development Review, 2(4), $337-359$. http://dx.doi.org/10.1177/1534484303257985.

Jolly, D. (2002). Sharing knowledge and decision power in Sino-foreign joint ventures. Asia Pacific Business Review, 9(2), 81-100. http:// dx.doi.org/10.1080/713999186.

Kathiravelu, S. R., Mansor, N., \& Kenny, K. (2013). Factors influencing knowledge sharing behaviour among employees of public services in Malaysia. International Journal of Academic Research in Economics and Management Sciences, 2(3), 107-119.

Klafke, R. V., Lievore, C., Picinin, C. T., de Francisco, A. C., \& Pilatti, L. A. (2016). Primary knowledge management practices applied in Brazil, Russia, India and China (BRIC) industries from 2001-2010. Journal of Knowledge Management, 20(4), 812-828. http:// dx.doi.org/10.1108/JKM-12-2015-0522.

Kulkarni, U. (2007). Knowledge management capability. Journal of Knowledge Management, 11(6), 94-109.

Kuo, F., \& Young, M. (2008). Predicting knowledge sharing practices through intention: a test of competing models. Computers in Human Behavior, 24(6), 2697-2722. http://dx.doi.org/10.1016/j.chb.2008.03.015.

Lang, N. S. (1998). Intercultural management in China. Wiesbaden: DUV.

Leung, T. K. P., \& Yee-kwong Chan, R. (2003). Face, favour and positioning: a chinese power game. European Journal of Marketing, 3711/12), 1575-1598. http://dx.doi.org/10.1108/03090560310495366.

Li, W., Downey, S., \& Wentling, T. (2008). Online knowledge sharing in a multinational corporation: Chinese versus American practices. Proceedings of the American Society for Information Science and Technology, 44(1), 1-13. http://dx.doi.org/10.1002/meet.1450440258.

Lin, C. (2007). To share or not to share: modelling knowledge sharing using exchange ideology as a moderator. Personnel Review, 36(3), 457-475. http://dx.doi.org/10.1108/00483480710731374.

Lin, H. F., Lee, H. S., \& Wang Da, W. (2009). Evaluation of factors influencing knowledge sharing based on a fuzzy AHP approach. Journal of Information Science, 35(1), 25-44. http://dx.doi.org/10.1177/0165551508091310.

Lin, T. M., Chang, H. C., \& Lin, C. W. (2010). Enhancing performance through merger and acquisition or strategic alliances. African Journal of Business Management, 5(14), 5929-5937.

Liu, M., \& Rao, P. (2015). A comparative perspective of knowledge management via social media: India and China. The Learning Organization, 22(2), 93-114. http://dx.doi.org/10.1108/TL0-03-2014-0010.

Ma, Z., Huang, Y., Wu, J., Dong, W., \& Qi, L. (2014). What matters for knowledge sharing in collectivistic cultures? Empirical evidence from China. Journal of Knowledge Management, 18(5), 1004-1019. http://dx.doi.org/10.1108/JKM-06-2014-0252.

Magnier-Watanabe, R., Benton, C., \& Senoo, D. (2011). A study of knowledge management enablers across countries. Knowledge Management Research \& Practice, 9(1), 17-28.

Mahmoud, M. (2008). Knowledge Management enablers and outcomes in the small-and medium sized enterprises. Industrial Management \& Data Systems, 109(6), 840-858.

Martinsons, M. G., \& Westwood, R. 1. (1997). Management information systems in the Chinese business culture: an explanatory theory. Information \& Management, 32(5), 215-228. http://dx.doi.org/10.1016/S0378-7206(96)00009-2.

Mayer, R. C., \& Gavin, M. B. (2005). Trust in management and performance: who minds the shop while the employees watch the boss?. Academy of Management Journal, 48(5), 874-888.

McAdam, R., Moffett, S., \& Peng, J. (2012). Knowledge sharing in Chinese service organizations: a multi case cultural perspective. Journal of Knowledge Management, 16(1), 129-147. http://dx.doi.org/10.1108/13673271211198981.

Mclnerney, D. M., \& Mclnerney, V. (2006). Educational psychology: constructing learning (4th ed.). Frenchs Forrest: Pearson.

Mesmer-Magnus, J. R., \& DeChurch, L. A. (2009). Information sharing and team performance: a meta-analysis. The Journal of Applied Psychology, 94(2), 535-546. http://dx.doi.org/10.1037/a0013773.

Miller, P. G., \& Strang, J. (2010). Addiction research methods. England: Wiley-Blackwell. http://dx.doi.org/10.1002/9781444318852.

Mooradian, T., Renzl, B., \& Matzler, K. (2006). Who trusts? Personality, trust and knowledge sharing. Management Learning, 37(4), 523-540. http://dx.doi.org/10.1177/1350507606073424.

Muniz Junior, J., Batista Junior, E. D., \& Loureiro, G. (2010a). Knowledge-based integrated Production Management Model applied to automotive companies. International Journal of Knowledge Management Studies, 4(3), 301-318. http://dx.doi.org/10.1504/ IJKMS.2010.038171.

Muniz Junior, J., Batista Junior, E. D., \& Loureiro, G. (2010b). Knowledge-based integrated production management model. Journal of Knowledge Management, 14(6), 858-871. http://dx.doi.org/10.1108/13673271011084907.

Muniz Junior, J., Hong, J., Costa, C. C., Pamplona, V. A. S., Pavlov, Y., Loureiro, G., \& Estudillo, M. N. V. (2014). Worker knowledge sharing assessment by analytic hierarchy structure: a theoretical approach. In Proceedings of the Conference for Organisational Learning, Knowledge and Capabilities (OLKC). Oslo, Norway: Norweigan Business School.

Mura, M., Lettieri, E., Radaelli, G., \& Spiller, N. (2013). Promoting professionals' innovative behaviour through knowledge sharing: the moderating role of social capital. Journal of Knowledge Management, 174), 527-544. http://dx.doi.org/10.1108/JKM-03-2013-0105.

Nakano, D. N., Muniz Junior, J., \& Batista Junior, E. D. (2013). Engaging environments: tacit knowledge sharing on the shop floor. Journal of Knowledge Management, 172), 290-306. http://dx.doi.org/10.1108/13673271311315222.

Nakano, D., \& Muniz Junior, J. (2018). Writing the literature review for an empirical paper. Production, 28, e20170086. http://dx.doi. org/10.1590/0103-6513.20170086.

Nascimento, L. O., Muniz Junior, J., Rocha, H. M., \& Rangel, L. A. D. (2017). Flexibility assessment to mitigate complexity: trucks production analysis. International Journal of the Analytic Hierarchy Process, 9(1), 48-63. 
Nisbett, R. E., Peng, K., Choi, 1., \& Norenzayan, A. (2001). Culture and systems of thought: holistic versus analytic cognition. Psychological Review, 108(2), 291-310. http://dx.doi.org/10.1037/0033-295X.108.2.291.

Nonaka, 1. (1994). A dynamic theory of organizational knowledge creation. Organization Science, 5(1), 14-37. http://dx.doi.org/10.1287/ orsc.5.1.14.

Nonaka, 1., \& Nishigushi, T. (2001). Knowledge emergence: social, technical and evolutionary dimensions of knowledge creation. New York: Oxford University Press.

Nonaka, 1., \& Takeuchi, H. (1995). The knowledge-creating company: How Japanese companies create the dynamics of innovation. USA: Oxford University Press.

Nonaka, 1., Von Krogh, G., \& Voelpel, S. (2006). Organizational knowledge creation theory: evolutionary paths and future advances. Organization Studies, 27(8), 1179-1208. http://dx.doi.org/10.1177/0170840606066312.

Organisation Internationale des Constructeurs d'Automobiles. (2018). Production statistics. Retrieved in 2018, February 10, from http:// www.oica.net/category/production-statistics/2017-statistics/

Paiva, E. L., Roth, A. V., \& Fensterseifer, J. E. (2007). Organizational knowledge and manufacturing strategy process: a resource-based view analysis. Journal of Operations Management, 26(1), 115-132. http://dx.doi.org/10.1016/j.jom.2007.05.003.

Park, M., Lee, H. S., \& Kwon, S. (2010). Construction knowledge evaluation using expert index. Journal of Civil Engineering and Management, 16(3), 401-411. http://dx.doi.org/10.3846/jcem.2010.46.

Peltokorpi, V. (2007). Intercultural communication patterns and strategies: nordic expatriates in Japan. International Business Review, 161(1), 68-82.

Polanyi, M. (2009). The tacit dimension. Chicago: University of Chicago Press.

Powell, K. M., Heerwagen, J. H., Kampschroer, K., \& Loftness, V. (2004). Collaborative knowledge work environments. Building Research and Information, 3(6), 510-528.

Probst, G., Romhardt, K., \& Raub, S. (2000). Managing knowledge: building blocks for success. USA: J. Wiley.

Rajkumar, R. (2001). Industrial knowledge management: a micro-level approach. London: Springer-Verlag.

Ramamurti, R., \& Singh, J. (2009). Emerging multinationals in emerging markets. Cambridge: Cambridge University Press. http://dx.doi. org/10.1017/CB09780511576485.

Rea, L. M., \& Parker, R. A. (2005). Design and conducting survey research: a comprehensive guide (3rd ed.). San Francisco: Jossey-Bass.

Redding, G. (1990). The spirit of chinese capitalism (de Gruyter Studies in Organization, Vol. 22). New York: de Gruyter. http://dx.doi. org/10.1515/9783110887709.

Redding, G. (2008). Separating culture from institutions: the use of semantic spaces as a conceptual domain and the case of China. Management and Organization Review, 4(2), 257-289. http://dx.doi.org/10.1111/j.1740-8784.2008.00103.x.

Ribiere, V. M., \& Zhang, Q. (2010). Expertise and mistakes, to share or not to share? A cross-cultural study of in-group/out-group relationships on knowledge sharing. In Proceedings of the 43rd Hawaii International Conference on System Sciences (pp. 1-10). Washington: IEEE Computer Society.

Riege, A. (2005). Three-dozen knowledge-sharing barriers managers must consider. Journal of Knowledge Management, 9(3), 18-35. http://dx.doi.org/10.1108/13673270510602746.

Ripamonti, S., \& Scaratti, G. (2012). Weak knowledge for strengthening competences: A practice-based approach in assessment management. Management Learning, 43(2), 183-197. http://dx.doi.org/10.1177/1350507611429911.

Saaty, T. (1980). The analytic hierarchy process. New York: McGraw-Hill.

Serenko, A., \& Bontis, N. (2004). Meta-review of knowledge management and intellectual capital literature: citation impact and research productivity ranking. Knowledge and Process Management, 11(3), 185-198. http://dx.doi.org/10.1002/kpm.203.

Siau, K., Erickson, J., \& Nah, F. F. (2010). Effects of national culture on types of knowledge sharing. IEEE Transactions on Professional Communication, 53(2), 278-292. http://dx.doi.org/10.1109/TPC.2010.2052842.

Silva, R. C., Dutra, J. S., Veloso, E. F. R., Fischer, A. L., \& Trevisan, L. N. (2015). Generational perceptions and their influences on organizational commitment. Management Research: Journal of the Iberoamerican Academy of Management, 13(1), 5-30.

Sinclair, N. (2007). The KM phoenix. VINE Journal of Information and Knowledge Management Systems, 37(3), $255-261$.

Søndergaard, S., Kerr, M., \& Clegg, C. (2007). Sharing knowledge: contextualising socio-technical thinking and practice. The Learning Organization, 14(5), 423-435.

Sorensen, S. Y. (2015). Motivating the solicited and unsolicited sharing of tacit knowledge through the process of externalization (Doctor thesis). Graduate School of Computer and Information Sciences, Nova Southeastern University, Fort Lauderdale.

Spender, J. C., \& Scherer, A. G. (2007). The philosophical foundations of knowledge management: editor's introduction. Organization, 14(1), 1-30. https://doi.org/10.1177/1350508407071858.

Statisca. (2018). Estimated passenger car production in selected countries in 2018, by country (in million units). Retrieved in 2018, January 10, from https://www.statista.com/statistics/226032/light-vehicle-producing-countries/

Styhre, A., Josephson, P.-E., \& Knauseder, 1. (2006). Organizational learning in non-writing communities: the case of construction workers. Management Learning, 37(1), 83-100. http://dx.doi.org/10.1177/1350507606060983.

Tang, J., \& Ward, A. (2003). The changing face of chinese management. Routledge: New York.

Taylor, E. Z., \& Murthy, U. S. (2009). Knowledge sharing among accounting academics in an electronic network of practice. Accounting Horizons, 23(2), 151-179.

Tohidinia, Z., \& Mosakhani, M. (2010). Knowledge sharing behaviour and its predictors. Industrial Management \& Data Systems, 110(4), 611-631. http://dx.doi.org/10.1108/02635571011039052.

Tonet, H. C., \& Paz, M. G. T. (2006). Um modelo para o compartilhamento de conhecimento no trabalho. Revista de Administração Contemporânea, 10(2), 75-94. http://dx.doi.org/10.1590/S1415-65552006000200005. 
Tong, J., \& Mitra, A. (2009). Chinese cultural influences on knowledge management practice. Journal of Knowledge Management, 13(2), 49-62. http://dx.doi.org/10.1108/13673270910942691.

Tsai, M., \& Lee, K.-W. (2006). A study of knowledge internalization: from the perspective of learning cycle theory. Journal of Knowledge Management, 10(3), 57-71. http://dx.doi.org/10.1108/13673270610670858.

Tynjälä, P. (2008). Perspectives into learning at the workplace. Educational Research Review, 3(2), 130-154.

Van den Hooff, B., \& De Ridder, J. A. (2004). Knowledge sharing in context: the influence of organizational commitment, communication climate and CMC use on knowledge sharing. Journal of Knowledge Management, 8(6), 117-130. http://dx.doi. org/10.1108/13673270410567675.

Wang, S., \& Noe, R. A. (2010). Knowledge sharing: a review and directions for future research. Human Resource Management Review, 20(2), 115-131. http://dx.doi.org/10.1016/j.hrmr.2009.10.001.

Wasonga, T., \& Murphy, J. F. (2006). Learning from tacit knowledge: the impact of the internship. International Journal of Educational Management, 20(2), 153-163. http://dx.doi.org/10.1108/09513540610646136.

Weir, D., \& Hutchings, K. (2005). Cultural embeddedness and contextual constraints: knowledge sharing in Chinese and Arab cultures. Knowledge and Process Management, 12(2), 89-98. http://dx.doi.org/10.1002/kpm.222.

Williamson, P., \& Zeng, M. (2009). Chinese multinationals: emerging through new global gateways. In R. Ramamurti and J. Singh (Eds.), Emerging multinationals in emerging markets (pp. 81-109). Cambridge: Cambridge University Press.

Wong, K. Y. (2005). Critical success factors for implementing knowledge management in small and medium enterprises. Industrial Management \& Data Systems, 105(3), 261-279. http://dx.doi.org/10.1108/02635570510590101.

Wong, K. Y., \& Aspinwall, E. (2004). Characterizing knowledge management in the small business environment. Journal of Knowledge Management, 8(3), 44-61. http://dx.doi.org/10.1108/13673270410541033.

Worley, M., \& Doolen, L. (2006). The role of communication and management support in a lean manufacturing implementation. Management Decision, 44(2), 228-245. http://dx.doi.org/10.1108/00251740610650210.

Yuanlin, X., Peng, G., Zengliang, L., \& Peng, X. (2011, August). Tacit knowledge sharing result evaluation based on improved AHP. In: Proceedings of the 2011 lEEE International Conference on Automation and Logistics (ICAL) (pp. 149-153). USA: IEEE.

Zhang, X., \& Jiang, J. Y. (2015). With whom shall 1 share my knowledge? A recipient perspective of knowledge sharing. Journal of Knowledge Management, 19(2), 277-295. http://dx.doi.org/10.1108/JKM-05-2014-0184. 
Appendix A. Questionnaire.

\section{Welcome}

Our University is conducting research in automotive industry. You have been invited to answer this questionnaire because of your experience and leadership with shop floor workers. The objective of the research is to evaluate the factors that in your opinion, contribute to better knowledge sharing among workers. We need your cooperation in answering this questionnaire. Certainly, you will answer it within minutes and this effort will be very useful to better know the shop floor and guide improvement opportunities in plants. Feel free to answer what you think, because the questions are simple and do not involve confidential aspects of where you work. The profile data is confidential.

Note the example below to help in your responses.

Example: For a football team gets victory in a match, check the degree of importance for the better alternative.

\begin{tabular}{cc}
\hline Importance of intensity & $\begin{array}{c}\text { Definition } \\
(\ldots \text { an alternative to the other })\end{array}$ \\
\hline 1 & Equal Importance \\
3 & Moderate importance \\
5 & Strong importance \\
7 & Very strong \\
9 & Extreme importance \\
\hline
\end{tabular}

\begin{tabular}{lllllllllllll} 
A & Players Individual skills & 9 & 7 & 5 & 3 & 1 & 8 & 5 & 7 & 9 & Integration among the players \\
B & Integration among the players & 9 & 7 & 5 & 3 & 1 & 3 & 5 & 7 & 9 & Number of fans in a match \\
\hline
\end{tabular}

A. This answer indicates that integration among the players was considered to have little importance (3) compared the individual skill of the players.

B. This answer indicates that integration between the players was considered to have great importance compared to number of fans in a game (7).

From now on, your judgment will be based on alternative known as Training, Job lnstruction, 5S and others. Here are some definitions to avoid doubts. Now use the same scale and check the degree of importance to the following alternatives:

- Resources: Roles and Responsibilities HR, Materials and Resources Time.

- Communication: Exchange of Information, ldeas and feeling.

- Incentives: reward or recognition.

\section{TO ANSWER PLEASE KEEP IN MIND THE OBJECTIVE OF BETTER SHARING KNOWLEDGE AMONG WORKERS}

To ensure improved Knowledge Sharing between Workers, based on the scale, check the relative significance to the following alternatives:

\begin{tabular}{lllllllllll}
\hline Conversation among plant workers & 9 & 7 & 5 & 3 & 1 & 3 & 5 & 7 & 9 & Update the work instruction \\
Update the work instruction & 9 & 7 & 5 & 3 & 1 & 3 & 5 & 7 & 9 & Studying the Standard Operating Procedure \\
Conversation among colleagues & 9 & 7 & 5 & 3 & 1 & 3 & 5 & 7 & 9 & Study the work instructions \\
\hline
\end{tabular}

To ensure improved conversation among plant workers, check the degree of relative importance to the following alternative: 


\begin{tabular}{lllllllllll}
\hline STRUCTURE & 9 & 7 & 5 & 3 & 1 & 3 & 5 & 7 & 9 & COMMUNICATION \\
COMMUNICATION & 9 & 7 & 5 & 3 & 1 & 3 & 5 & 7 & 9 & TRAINING \\
TRAINING & 9 & 7 & 5 & 3 & 1 & 3 & 5 & 7 & 9 & INCENTIVE \\
INCENTIVE & 9 & 7 & 5 & 3 & 1 & 3 & 5 & 7 & 9 & PROBLEM SOLVING METHODOLOGY \\
PROBLEM SOLVING METHODOLOGY & 9 & 7 & 5 & 3 & 1 & 3 & 5 & 7 & 9 & WORK INSTRUCTION \\
STRUCTURE & 9 & 7 & 5 & 3 & 1 & 3 & 5 & 7 & 9 & TRAINING \\
COMMUNICATION & 9 & 7 & 5 & 3 & 1 & 3 & 5 & 7 & 9 & INCENTIVE \\
TRAINING & 9 & 7 & 5 & 3 & 1 & 3 & 5 & 7 & 9 & PROBLEM SOLVING METHODOLOGY \\
INCENTIVE & 9 & 7 & 5 & 3 & 1 & 3 & 5 & 7 & 9 & WORK INSTRUCTION \\
STRUCTURE & 9 & 7 & 5 & 3 & 1 & 3 & 5 & 7 & 9 & INCENTIVE \\
COMMUNICATION & 9 & 7 & 5 & 3 & 1 & 3 & 5 & 7 & 9 & PROBLEM SOLVING METHODOLOGY \\
TRAININING & 9 & 7 & 5 & 3 & 1 & 3 & 5 & 7 & 9 & WORK INSTRUCTION \\
STRUCTURE & 9 & 7 & 5 & 3 & 1 & 3 & 5 & 7 & 9 & PROBLEM SOLVING METHODOLOGY \\
COMMUNICATION & 9 & 7 & 5 & 3 & 1 & 3 & 5 & 7 & 9 & WORK INSTRUCTION \\
STRUCTURE & 9 & 7 & 5 & 3 & 1 & 3 & 5 & 7 & 9 & WORK INSTRUCTION \\
\hline
\end{tabular}

To ensure improved registration in Job Instruction, check the degree of relative importance to the following alternative:

\begin{tabular}{lllllllllll}
\hline STRUCTURE & 9 & 7 & 5 & 3 & 1 & 3 & 5 & 7 & 9 & COMMUNICATION \\
COMMUNICATION & 9 & 7 & 5 & 3 & 1 & 3 & 5 & 7 & 9 & TRAINING \\
TRAINING & 9 & 7 & 5 & 3 & 1 & 3 & 5 & 7 & 9 & INCENTIVE \\
INCENTIVE & 9 & 7 & 5 & 3 & 1 & 3 & 5 & 7 & 9 & PROBLEM SOLVING METHODOLOGY \\
PROBLEM SOLVING METHODOLOGY & 9 & 7 & 5 & 3 & 1 & 3 & 5 & 7 & 9 & WORK INSTRUCTION \\
STRUCTURE & 9 & 7 & 5 & 3 & 1 & 3 & 5 & 7 & 9 & TRAINING \\
COMMUNICATION & 9 & 7 & 5 & 3 & 1 & 3 & 5 & 7 & 9 & INCENTIVE \\
TRAINING & 9 & 7 & 5 & 3 & 1 & 3 & 5 & 7 & 9 & PROBLEM SOLVING METHODOLOGY \\
INCENTIVE & 9 & 7 & 5 & 3 & 1 & 3 & 5 & 7 & 9 & WORK INSTRUCTION \\
STRUCTURE & 9 & 7 & 5 & 3 & 1 & 3 & 5 & 7 & 9 & INCENTIVE \\
COMMUNICATION & 9 & 7 & 5 & 3 & 1 & 3 & 5 & 7 & 9 & PROBLEM SOLVING METHODOLOGY \\
TRAININING & 9 & 7 & 5 & 3 & 1 & 3 & 5 & 7 & 9 & WORK INSTRUCTION \\
STRUCTURE & 9 & 7 & 5 & 3 & 1 & 3 & 5 & 7 & 9 & PROBLEM SOLVING METHODOLOGY \\
COMMUNICATION & 9 & 7 & 5 & 3 & 1 & 3 & 5 & 7 & 9 & WORK INSTRUCTION \\
STRUCTURE & 9 & 7 & 5 & 3 & 1 & 3 & 5 & 7 & 9 & WORK INSTRUCTION \\
\hline
\end{tabular}

To ensure improved understanding the Work Instruction, check the degree of relative importance to the following alternative:

\begin{tabular}{lllllllllll}
\hline STRUCTURE & 9 & 7 & 5 & 3 & 1 & 3 & 5 & 7 & 9 & COMMUNICATION \\
COMMUNICATION & 9 & 7 & 5 & 3 & 1 & 3 & 5 & 7 & 9 & TRAINING \\
TRAINING & 9 & 7 & 5 & 3 & 1 & 3 & 5 & 7 & 9 & INCENTIVE \\
INCENTIVE & 9 & 7 & 5 & 3 & 1 & 3 & 5 & 7 & 9 & PROBLEM SOLVING METHODOLOGY \\
PROBLEM SOLVING METHODOLOGY & 9 & 7 & 5 & 3 & 1 & 3 & 5 & 7 & 9 & WORK INSTRUCTION \\
STRUCTURE & 9 & 7 & 5 & 3 & 1 & 3 & 5 & 7 & 9 & TRAINING \\
COMMUNICATION & 9 & 7 & 5 & 3 & 1 & 3 & 5 & 7 & 9 & INCENTIVE \\
TRAINING & 9 & 7 & 5 & 3 & 1 & 3 & 5 & 7 & 9 & PROBLEM SOLVING METHODOLOGY \\
INCENTIVE & 9 & 7 & 5 & 3 & 1 & 3 & 5 & 7 & 9 & WORK INSTRUCTION \\
STRUCTURE & 9 & 7 & 5 & 3 & 1 & 3 & 5 & 7 & 9 & INCENTIVE \\
COMMUNICATION & 9 & 7 & 5 & 3 & 1 & 3 & 5 & 7 & 9 & PROBLEM SOLVING METHODOLOGY \\
TRAININING & 9 & 7 & 5 & 3 & 1 & 3 & 5 & 7 & 9 & WORK INSTRUCTION \\
STRUCTURE & 9 & 7 & 5 & 3 & 1 & 3 & 5 & 7 & 9 & PROBLEM SOLVING METHODOLOGY \\
COMMUNICATION & 9 & 7 & 5 & 3 & 1 & 3 & 5 & 7 & 9 & WORK INSTRUCTION \\
STRUCTURE & 9 & 7 & 5 & 3 & 1 & 3 & 5 & 7 & 9 & WORK INSTRUCTION \\
\hline
\end{tabular}


RESPONDENT'S PROFILE (who works or has worked directly with workers)

Name: E-mail:

Time of Industry Experience [years]:

Time as executive [years]:

Do you work directly in the Production area?? Yes ( ) No ( )

If "Yes "was your answer, in which area are you working?

Your current position:

If "No" was your answer, have you ever worked in the production area? Yes ( ) No ( )

Was it easy to understand the questions? Yes ( ) No ( )

If "No" was your answer, tell us what you think it was hard to understand:

Notes and/or comments: 